GLOBAL JOURNAL OF PURE AND APPLIED SCIENCES VOL. 21, 2015: 7-12

COPYRIGHT@ BACHUDO SCIENCE CO. LTD PRINTED IN NIGERIA ISSN 1118-0579 www.globaljournalseries.com, Email: info@globaljournalseries.com

\title{
PREVALENCE OF INTESTINAL PARASITES IN VEGETABLES SOLD IN MAJOR MARKETS IN IBADAN CITY, SOUTH-WEST NIGERIA
}

ADEJAYAN ADEJUMOKE AND OLAJUMOKE MORENIKEJI

(Received 24 October 2014; Revision Accepted 19 February 2015)

\begin{abstract}
Studies were carried out in Ibadan City, South-West Nigeria between March and June 2011, to determine the prevalence of intestinal parasites in vegetables sold in various markets within the city. Fifty samples each of 5 different vegetable types, Cabbage (Brassica deracea), Lettuce (Lactus sativa), Carrot (Daucus carota), Cucumber and green leafy vegetables were bought randomly from five different markets and examined for parasites in the laboratory using sedimentation method. Results show that $29(11.6 \%)$ out of the 250 vegetable samples examined had intestinal parasites. The prevalence of intestinal parasites in these plant tissues was found to be $22.0 \%$ in Cabbage, $14.0 \%$ in Carrot, $12.0 \%$ in lettuce and $10.0 \%$ in Green leafy vegetables. No parasites were detected in the 50 cucumber samples. Intestinal parasites detected included ova of Ascaris lumbricoides (51.7\%), Hookworm larvae (27.6\%) and larvae of Strongyloides stercoralis (20.7\%). This study shows a high prevalence of intestinal parasites on vegetables in Ibadan markets and the need for public enlightenment campaigns on the danger of consuming inadequately washed and raw vegetables.
\end{abstract}

KEYWORDS: Intestinal parasites, vegetable, market, sedimentation technique, South-West Nigeria.

\section{INTRODUCTION}

Vegetables are commonly referred to as fresh edible portions of herbaceous plant roots, stems, leaves or fruits. In many countries, vegetables are eaten raw or lightly cooked to preserve taste and this practice may favour the transmission of food-borne parasitic infections (Ozlem and Sener, 2005). Food normally becomes a potential source of human infection when contaminated during production, collection, transportation and preparation or during processing (Damen et al., 2007; Daryani et al., 2008).

Green leafy vegetables are seasonal crops which thrive well both in the spring and in the fall. In many tropical countries, vegetables are grown throughout the year using rain water during the wet season and irrigation during the dry season. Irrigation water is derived from two sources; rivers and mine ponds which are highly contaminated with human and animal faeces. The use of such contaminated irrigation water is a health risk to the farmers and consumers of the crops so produced (Okoronkwo, 1998).

Raw waste water usually contains high contamination of eggs of human intestinal nematodes and the increasing use of wastewater for irrigation in the 1970 s and early 1980s prompted a series of literature reviews and investigation into the global extent of waste water re-use and its associated human health risk (Ayer et al., 1992). Infection can also be a household problem where infected children or persons provide the chief source of soil contamination by their promiscuous defecation in the soils. Furthermore, market vegetables are often contaminated by eggs of human intestinal nematodes where night soil is extensively used as fertilizers. Both crop consumers and the agricultural workers have been identified as being at high risk of soil and wastewater transmitted infections.

The direct application of night soil, animal manure and wastewater as agricultural fertilizer has been practiced for centuries in many parts of the world. The practice is gaining prominence in developing countries as a result of the increasing cost of mineral fertilizers as well as the increasing demand for basic food supplies (Shuval et al., 1986). In addition, indirect reuse of river water which contains a substantial percentage of municipal refuse and sewage practised in many developing countries (WHO, 1989).

In recent years, there has been an increase in the number of reported cases of food-borne illnesses linked to the consumption of fresh vegetables (AlMegrin, 2010). Several surveys in different parts of the world showed that the vegetables can be agent for transmission of protozoan cysts and oocysts (Giardia, Entamoeba, Cryptosporidium, Cyclospora, Toxoplasma and Isospora) and helminth eggs and larvae (Hymenolepis, Taenia, Fasciola, Toxocara, Ascaris, Trichostrongylus, Strongyloides and Hookworms) (De Oliveira and Germano, 1992; Darchenkova et al., 2006; Vuong et al., 2007). Intestinal parasitic infections are among the most common infections worldwide (Pozio, 2008). Various epidemiological studies have indicated that the prevalence of intestinal parasites is high especially in developing countries, although in many of these, the environmental risk factors have not been clearly elucidated (Nyarango et al., 2008).

This study aims at evaluating the prevalence of intestinal parasites in vegetables sold in various markets in Ibadan city, South-West Nigeria. 


\section{MATERIALS AND METHODS}

\section{Study Area}

This study was carried out in Ibadan North Local Government Area (LGA), Oyo state, south-west Nigeria between March and June, 2011. It is located on longitude $3^{\circ} 58^{1}$ East of the Greenwich meridian and latitude $7^{\circ} 22^{1}$ North of the equator. Ibadan North LGA headquarters is in Bodija which has an area of $27 \mathrm{~km}^{2}$ and a population of 306,795 at the 2006 census.

Rainfall is highest between June and September with mean daily temperature fluctuating between $20.6^{\circ} \mathrm{C}$ and $35.0^{\circ} \mathrm{C}$, while dry season ranges between November and March when the daily maximum temperature exceeds $35.0^{\circ} \mathrm{C}$.

The markets situated in this LGA are found in Ode-Oolo, Sabo, Basorun, Sango, Mokola, Bodija, Agodi, Agbowo, New Gbagi, Sasa, Ojoo, Oke-Itunu and Temidire Ife road.

\section{Sample Collection}

The vegetables used in this study include Cabbage (Brassica deracea), lettuce (Lactus sativa), Carrot (Daucus carota), Cucumber and Green leafy vegetable.

Vegetables were bought randomly from five markets, Bodija, Ojoo, Sabo, Sango and Mokola markets; the major markets where farmers from different locations within the State bring their farm produce for sale. These markets also serve as the central areas for receiving products from other states before their final distribution into other markets within the city.

\section{Processing of the Samples}

\section{Macroscopic examination}

Each of the samples were examined macroscopically for the presence of segments of cestodes and adult nematodes

\section{Procedure for washing the samples}

Two hundred gram weight of each vegetable sample was placed separately in a plastic container and washed with $10 \mathrm{ml}$ physiological saline solution $(0.95 \% \mathrm{NaCl})$ for the removal of parasitic ova, cysts or larva. The water used to wash the vegetable was left for 5 hours for sedimentation to take place and then the top layer was discarded and the remaining was transferred into a 10 $\mathrm{ml}$ test tube and centrifuged at $2000 \mathrm{rpm}$ for 20 minutes (Al-Megrin, 2010). After centrifugation the supernatant was discarded into the disinfectant jar and the sediment was resuspended. A drop of the suspension was applied to the centre of a clean glass slide and a drop of Lugols iodine was applied. A clean cover slip was placed gently on slide to avoid air bubbles. The preparation was examined under the microscope using X10 and X40 objectives.

\section{Data analysis}

The overall prevalence of the parasites was calculated. Chi square and 2-way ANOVA were used for multiple comparisons between rates of parasite recovery and $\mathrm{p}<0.05$ was considered significant.

\section{RESULTS}

Of a total of 250 samples of five vegetable types examined for intestinal parasites, $29(11.6 \%)$ were positive for intestinal parasites. Cabbage had $11(22 \%)$, the highest number of samples contaminated with intestinal parasites, followed by Carrot $7(14.0 \%)$ and Lettuce $6(12.0 \%)$. Parasites were not detected in all the 50 samples of cucumber (Table 1). Three nematode stages recovered from the samples included eggs of Ascaris lumbricoides, larvae of Strongyloides stercoralis and rhabditiform larvae of hookworm.

Table 1: Total Number of vegetable samples positive for parasites from all markets surveyed

\begin{tabular}{l|l|l}
\hline \multicolumn{1}{c|}{ Vegetable } & $\begin{array}{l}\text { Total No of samples } \\
\text { examined }\end{array}$ & $\begin{array}{l}\text { No of samples positive for } \\
\text { parasites }(\%)\end{array}$ \\
\hline Cabbage & 50 & $11(22.0)$ \\
Lettuce & 50 & $6(12.0)$ \\
Carrot & 50 & $7(14.0)$ \\
Cucumber & 50 & $0(0.0)$ \\
Green leafy types & 50 & $5(10.0)$ \\
Total & 250 & $29(11.6)$ \\
\hline
\end{tabular}

Table 2 shows the number of vegetable samples positive for parasites in each market surveyed. Sabo market had significantly more contaminated samples [12(24.0\%)] followed by Mokola market $[8(16.0 \%)]$ and Bodija market [5(10.0\%)] while the lowest contamination [2(4.0\%)] was observed in Sango 
and Ojoo markets. Half (50.0\%) of the contaminated cabbage samples were from Sabo.

Table 3 shows the frequency of isolated intestinal parasites in all the vegetables examined. Ascaris lumbricoides had the highest prevalence [15(51.7\%)] followed by Hookworm [8(27.6\%)] while Strongyloides stercoralis had the least [6(20.7\%)]. Frequency values were statistically different $(p<0.05)$.
Table 4 shows the mean number of parasite eggs/larvae per 200 gram in each vegetable. Cabbage recorded the highest number of mean eggs/larvae count (3.1) while green leafy vegetable recorded the least (1.6).

The highest recovery rate of intestinal parasites was recorded in April (13.3\%) while the least rate was recorded in June (9.3\%) (Table 5). 


\begin{tabular}{|c|c|c|c|c|c|c|c|c|c|c|c|c|}
\hline Vegetables & $\begin{array}{l}\text { Bodija } \\
\text { Examined }\end{array}$ & $\begin{array}{c}\text { Contaminated } \\
(\%)\end{array}$ & $\begin{array}{l}\text { Sango } \\
\text { Examined }\end{array}$ & $\begin{array}{c}\text { Contaminated } \\
(\%)\end{array}$ & $\begin{array}{l}\text { Mokola } \\
\text { Examined }\end{array}$ & $\begin{array}{c}\text { Contaminated } \\
(\%)\end{array}$ & $\begin{array}{l}\text { Sabo } \\
\text { Examined }\end{array}$ & $\begin{array}{l}\text { Contaminated } \\
(\%)\end{array}$ & $\begin{array}{l}\text { Ojoo } \\
\text { Examined }\end{array}$ & $\begin{array}{c}\text { Contaminated } \\
(\%)\end{array}$ & $\begin{array}{l}\text { Total } \\
\text { Examined }\end{array}$ & $\begin{array}{c}\text { Contaminated } \\
(\%)\end{array}$ \\
\hline Cabbage & 10 & $2(20.0)$ & 10 & $0(0.0)$ & 10 & $4(40.0)$ & 10 & $5(50.0)$ & 10 & $0(0.0)$ & 50 & 11(22.0) \\
\hline Lettuce & 10 & $1(10.0)$ & 10 & $0(0.0)$ & 10 & $2(20.0)$ & 10 & $2(20.0)$ & 10 & $1(10.0)$ & 50 & $6(12.0)$ \\
\hline Carrot & 10 & $1(10.0)$ & 10 & $1(10.0)$ & 10 & $1(10.0)$ & 10 & $4(40.0)$ & 10 & $0(0.0)$ & 50 & $7(14.0)$ \\
\hline Cucumber & 10 & $0(0.0)$ & 10 & $0(0.0)$ & 10 & $0(0.0)$ & 10 & $0(0.0)$ & 10 & $0(0.0)$ & 50 & $0(0.0)$ \\
\hline $\begin{array}{l}\text { Green leafy } \\
\text { types }\end{array}$ & 10 & $1(10.0)$ & 10 & $1(10.0)$ & 10 & $1(10.0)$ & 10 & $1(10.0)$ & 10 & $1(10.0)$ & 50 & $5(10.0)$ \\
\hline Total & 50 & $5(10.0)$ & 50 & $2(4.0)$ & 50 & $8(16.0)$ & 50 & $12(24.0)$ & 50 & $2(4.0)$ & 250 & $29(11.6)$ \\
\hline
\end{tabular}


Table 3: Frequency of isolated intestinal parasites in the vegetables examined

\begin{tabular}{l|c|c}
\hline Parasites & Frequency of isolation & Percentage (\%) \\
\hline Ascaris lumbricoides & 15 & 51.7 \\
Hookworm & 8 & 27.6 \\
Strongyloides stercoralis & 6 & 20.7 \\
Total & 29 & 100.0 \\
\hline
\end{tabular}

$X^{2}=40.21^{*}$

$X^{2}$ critic $=5.991$

Table 4: Mean number of parasite eggs/larvae per 200 grams of each vegetable

\begin{tabular}{lccccc}
\hline & Cabbage & Lettuce & Carrot & Cucumber & Green leafy \\
\hline $\begin{array}{l}\text { No of vegetable } \\
\text { Examined }\end{array}$ & 50 & 50 & 50 & 50 & 50 \\
$\begin{array}{l}\text { Total vegetable } \\
\text { Weight }(\mathrm{g})\end{array}$ & 10,000 & 10,000 & 10,000 & 10,000 & 10,000 \\
$\begin{array}{l}\text { Total number of } \\
\text { Eggs/larvae found }\end{array}$ & 153 & 98 & 147 & ND & 78 \\
$\begin{array}{l}\text { Mean number of eggs/ } \\
\text { Larvae per } 200 \mathrm{~g} \text { of } \\
\text { Vegetable }\end{array}$ & 3.1 & 2.0 & 2.9 & ND & 1.6 \\
\end{tabular}

*ND: Not detected

\section{DISCUSSION}

Food-borne parasitic infections have received little attention in developing countries. As a rule, parasitic organisms which contaminate vegetables while still on the field and are usually transmitted by contaminated water and spread by ineffective hygienic practise (Silvia et al., 2007). The findings from this study have shown that parasitic eggs and larvae can be found at harvest on vegetables. Of the 250 samples of vegetables that were collected, processed and examined, 29 (11.6\%) of them were contaminated with parasites. This result is similar to the study carried out by Yakhchali and Ahmadiashtiani (2004) in Urmia, where $12.6 \%$ parasitic contamination was recorded and Al-Megrin (2010) in Riyadh, Saudi Arabia where 16.2\% vegetables were positive for intestinal parasite stages.

Results from this study which show that Cabbage had the highest parasitic contamination $(22.0 \%)$ and green leafy vegetable recorded the lowest $(10.0 \%)$ while the 50 samples from Cucumber had no parasite, could be due to the fact that the degree of contamination varies according to vegetables. Cabbage, Lettuce and green leafy vegetables have uneven surfaces which make parasitic eggs, larvae attach to them more easily, either in the farm or when washed with contaminated water while Cucumber had the least prevalence presumably because of its smooth surface which reduces the rate of parasitic attachment.

Sabo market recorded the highest prevalence $(24.0 \%)$ of infected vegetable samples followed by Mokola market (16.0\%) and Bodija market (10.0\%). The high prevalence of contamination with parasites on vegetables might be due to the fact that these open markets are characterized by the presence of refuse dump sites, poor drainage, improper disposal of faeces of traders and poor hygienic practices. This is in addition to preceding contamination of vegetables arriving from rural areas around and outside these markets.

Three different types of intestinal parasites (nematodes) were isolated. These parasites included eggs of Ascaris lumbricoides [15 (51.7\%)], larvae of Hookworm [8 (27.6\%)] and larvae of Strongyloides stercoralis [6 (20.7\%)]. Variation in the parasites recorded may be due to differences in the geographical location of the study. However, the intestinal parasites isolated from this study were not as many and differ from those isolated from other parts of Nigeria (Damen et al, 2007, Ogunleye et al 2010, Idahosa 2011, Alade et al, 2013) due to the fact that some of these vegetables like carrot, cabbage and lettuce were transported from the northern areas into the state for consumption. During the process of harvesting and transportation, some of these parasites might have been destroyed. Despite variation in isolated parasites, Ascaris lumbricoides and Hookworm were common to all vegetables in all the studies. This could be due to the fact that these parasites can withstand a wide variety of adverse environmental conditions. Monthly prevalence of parasites recovered was highest in April and decreased in June. This is because rainfall is scanty in April when farmers use wastewater to improve crop growth but the rains usually become heavy as from May, thus reducing parasite rate with each downpour.

Faecal contamination of water sources used in crop irrigation is an important source of human infection and contamination of fresh vegetables are of greatest concern (Orlandi et al, 2002). Shuval et al (1986) observed that there is evidence that people consuming vegetables irrigated with raw waste water are exposed 
to the risk of infection with Ascaris, Trichuris, Amoeba and Tapeworm.

The consumption of raw vegetable plays an important role in the transmission of parasitic infections (Anuar, 1977). Recovery of parasites from vegetables may be helpful in indicating the incidence of intestinal parasites in a community.

The high level of vegetable contamination with parasitic stages in this study is significant hence control measures will therefore include treatment of irrigation water, municipal wastewater before use, treatment of infected persons and mass education of the populace on the inherent danger in eating inadequately washed or raw vegetables. Provision of good sanitary system in the rural and urban areas to prevent contamination of soil and water with parasites from faecal matter should be adopted.

There is a need for improved surveillance systems on food-borne pathogens, on food products through adequate vegetable farming procedures, improved transportation and storage facilities in the various market destinations.

\section{REFERENCES}

Alade, G. O., Alade, T. O and Adewuyi, I. K., 2013. Prevelance of Intestinal parasites in Vegetables Sold in Ilroin, Nigeria. American- Eurasian J. Agric and Environ. Sci. 13, (9): 1275- 1282.

Al-Megrin, WAI., 2010. Prevalence of intestinal parasites in leafy vegetables in Riyadh, Saudi Arabia. Int. J. Zool. Res., (6): 190-195.

Anuar A. K and Ramachandran C. P., 1977. A study on the prevalence of soil transmitted helminths among lettuce leaves sold in local markets in Penang, Malaysia. Med. J. Malaysia., (31): 262265.

Ayer R. M., Scott, R., Lee, D. D and Silve, S. A., 1992. Contamination of lettuce with nematode eggs by spray irigation with treated and untreated waste water. Water Sci. and Tech.., (26): 1615-1623.

Damen J. G., Banwat, E. B., Egah, D. Z and Allanana, J. A., 2007. Parasitic contamination of vegetable in Jos, Nigeria. Ann of Af. Med. 6, (3):115-118.

Darchenkova, N. N., Romanenko, N. A and. Chernyshenko, A. I., 2006. Current ascariasis situation in the Russian federation. Med. Parasitol., (4): 40-43.

Daryani, A, G. H., Ettehad, M., Sharif, L., Ghorbani and Ziaei, H., 2008. Prevalence of intestinal parasites in vegetables consumed in Ardabil, Iran. Food Cont. (19): 790-794.

De Oliveira, C. A and Germano, P. M., 1992. Presence of intestinal parasites in vegetables sold in the metropolitan region of Sao Paulo, SP, Brazil. ISearch of helminths. Rev. Saudi Publica, 26: 283-289.
Idahosa, O. T., 2011. Parasitic contamination of fresh vegetables sold in Jos Markets. Global Journal of Medical research. 11, (1): 20-25.

Nyarango, R. M., Aloo, P. A., Kabiru, E. W and Nyanchongi, B. O., 2008. The risk of pathogenic intestinal parasite infections in Kisii Municipality, Kenya. BMC Public Health, (8): 237-237.

Ogunleye, V. F., Babatunde, S. K and Ogbolu, D. O., 2010. Parasitic contamination of Vegetables from some markets In South- Western Nigeria. Tropical Journal of Health Sciences. 17, (2):

Okoronkwo, M. O., 1998. Intestinal parasites associated with human and animal waste stabilization in Jos and Barkin Ladi areas of Plateau State, Nigeria. PhD Thesis, University of Jos, Jos.

Orlandi, P. A., Chu, D. M. T and Bier, J. W., 2002. Inorganic fertilizers at affordable rates to farmers in order to discourage the use of faeces as fertilizers. Parasites and food suppl. Technol., 56, (4): 72-81.

Ozlem, E and Sener, H., 2005. The contamination of various fruit and vegetable with Enterobius vermicularis, Ascaris eggs, Entamoeba histolytica cysts and Giardia lamblia cysts. J. Food Cont., (16): 557-560.

Pozio, E., 2008. Epidemiology and control prospects of foodborne parasitic zoonoses in the European Union. J. Parasitol, (50): 17-24.

Shuval, HI., Adon, A., Fattai, B., Rawitz, E and Yukiel, P., 1986. Waste water irrigation in developing countries; health effect and technical solution. World Bank Technical Paper; 51.

Silvia, R. D. S., Sylvia, E. F. V., Dariene, C. P., Ahie, M. $S$ and Gertrudes, C., 2007. Microbiological quality of minimally processed vegetables sold in Porto Alegre, Brazil. Brazilian J. Microbiol., (38): 594598.

Vuong, T. A., Nguyen, T. T., Klank, L. T., Phung, D. C and Dalsgaard, A., 2007. Faecal and protozoan parasite contamination of water spinach (Ipomoea aquatica) cultivated in urban wastewater in Phnom Penh, Cambodia. Trop. Med. Int. Health, (12): 73-81.

World Health Organisation., 1989. Health guidelines for the use of waste water in agriculture. WHO, Geneva, Technical Report Series. 778.

Yakhchali, M and Ahmadiashtiani H. R., 2004. Survey of the parasite transmission role of fresh vegetables in Urmia city, Iran. Southeast Asian J Trop Med Public Health 35 (Supp/ 1): 147-149. 
